\title{
Grundtvig og Shakespeare
}

\author{
Af Morten Bredsdorff \\ »Nu saadan en Række Optrin af Kæmpe-Livets Un- \\ dergang, som dem, Shakspear var fri nok for at \\ udtømme, skal vist nok Ingen misunde England; \\ men hvad siger man om den Kraft, der teede sig i \\ dem, den Kraft, hvoraf selv Skygger paa Skue-Plad- \\ sen synes os Gigantiske, den Kraft og det Falke-Blik i \\ Menneske-Livets Dybder, som Shakspear forudsæt- \\ ter!«
}

Nordens Mythologi, 1832.

Næst efter Holbergs Levnedsbreve findes der i dansk literatur næppe noget værk, der så stærkt er båret af sindets humor og folkelig munterhed som Grundtvigs »Nordens Mythologi eller Sindbilled-Sprog, historisk-poetisk udviklet og oplyst«, 2. omarbeidede Udgave 1832 (som den beskedent kaldes med et tilbageblik på den vidt forskellige Nordens Mythologi fra 1807/o8, hvis sigte var rent videnskabeligt og som fik så stor betydning for forskningen). Med rette bemærker forfatteren i sin fortale, »næst Kiedsommelighed lader dog ingen Sinds-Stemning sig bedre meddele ved Pennen end Munterhed « en betragtning han selv har holdt sig for øje, og som måske i for ringe grad præger en del af den mere videnskabelige behandling af det store forfatterskab. Denne tykke bog lunes virkelig af en moden mands sunde og muntre livsstemning, tydelig nok frugten af de $\gg$ tre Engelske Rejser (1829-3I) med særdeles Hensyn på de Angelsaxiske Haandskrifter i London, Exeter, Oxford og Cambridge, hvor han lærte at kjende det borgerlige og videnskabelige Liv fra en ham splinterny Side«. (Selvbiografi i Erslews Forfatter-Lexicon, I43, I. bind, p. 509).

Lykkeligvis blev de ialt I I, temmelig trælse studiemåneder med oldengelske manuskripter krydret af levende indtryk af det liberale 
og kapitalistiske Englands kraftfulde borgerlige foretagsomhed. Den indeklemte, provinsielle atmosfære fra det lille kongerige ved Østersøen vejredes bort af det atlantiske øriges friske og skarpe luft. Det videnskabelige udbytte af disse rejser, en bedre tekst til Beowulfskvadet, en dybere indsigt i nordisk oldhistorie og et kraftigt skub til engelske forskere om selv at tage fat på forskningen af landets egen ældste digtning, er velkendt og oftere behandlet. Ligesom det frie akademiske fællesskab, især på Trinity College i Cambridge, jo klart har påvirket Grundtvigs tanker om en fri folkelig højskole.

Mindre kendt er det måske, at den danske digter tillige må have fundet tid til i forbausende omfang at sætte sig ind i nyere engelsk digtning fra Chaucer og Shakespeare ned til sine samtidige Lord Byron og Walter Scott. Frem for alt synes han at have tilegnet sig en på den tid for en dansker ret enestående fortrolighed med Shakespeares skuespil. Det førte til en helt ny vurdering af den store Elizabethanske dramatiker og hans betydning ${ }^{1}$ ).

\section{I.}

Shakespeares navn har Grundtvig kendt helt fra unge år. Om ikke før mødte han det i Henrik Steffens forelæsninger 1804-05, der handlede om »Goethe, Shakespeare, Cervantes, Tieck og Novalis«, og som både Grundtvig og Oehlenschlæger hørte. Den sidste bekræfter i sine erindringer, at han efter Steffens forelæsninger »læste høit for hende (søsteren) og Ørstederne næsten hver Aften. De Værker, som vi i den Tid nøde med hverandre, og om hvilke vi siden talede og dømte, vare: Vosses Homer, Tiecks Don Quixote, Schlegels Shakespeare, og Calderon, Goethes, Schillers, Tiecks og Novalis Værker«. Det tyske sprogs dominans i den unge digters literære dannelsesvej er umiskendeligt.

Det samme gælder Grundtvig. I en dagbogsoptegnelse fra maj I 804 nævnes Addison »Spectator« nr. I6o, der drøfter forholdet mellem

I. Grundtvigs interesse for England og engelsk litteratur er behandlet af mange forskere, bl. a. Helge Toldberg (dels i hans disputats Grundtvigs Symbolverden, 1950, dels i Grundtvig-Studier 1964 (s. 21), hvor Grundtvigs læsning af Byron er fremdraget) og Andreas Haarder (Grundtvig-Studier 1965 og 1968). Jævnfør Toldbergs afhandling i Orbis Litterarum V (1947) s. 258-3 I I. Grundtvigs beundring for Shakespeare er tidligere taget op af Alf Henriques i hans disputats Shakespeare og Danmark indtil 1840 , København I94r, s. 97-ro I og flere steder. 
»geni« og »kunst«. Et vist forbehold over for genidyrkelse præger Grundtvigs egne betragtninger; men han gør en betydningsfuld indrømmelse: »Når Man betragter Shakesspear, da tør man ikke ønske ham dannet ved Kunst og Læsning.« I en dagbogsoptegnelse fra Io. september 1805 nævner han påny »Skakspear« (hvordan mon han har udtalt navnet?) og formulerer sin voksende tilslutning til den nye romantiske skole. »I Hovedsagen maae Jeg da bekende Mig til de ny Poeters Tro, uden derfor at indrømme, hvad De ville, at der, paa Skakspear og nogle Italiænere samt Levninger af Provensalerne nær, ingen Digter var til fra Grækernes blomstrende Tid indtil Goethe.« Baggrunden er endnu næppe så meget læsning af de shakespeareske skuespil som Henrik Steffens forelæsninger. Herom hedder det i Mands Minde under omtalen af Steffens (XXV): »Og nu Bedømmelsen af de navnkundige Digtere, Lovprisningen af Shakspeare og Cervantes, Goethe, Tieck og Novalis, som jeg slet ikke kjendte, Lovprisningen fra saa veltalende Læber og med en Begejstring, der hjemlede sig selv en Stemme om Begejstring, den maatte nødvendig spænde min Opmærksomhed -«

Den unge Grundtvig fulgte Henrik Steffens opfordring og gav sig til at læse Shakespeare. »Til Shakspears, Goethes, Schillers og Ossians Harper har jeg i min Eensomhed lyttet « (Danne-Virke III, I 8I 7) men næppe på engelsk, som han på denne tid ikke magtede. Som sin digterfrænde Oehlenschlæger greb han A. W. Schlegels fremragende tyske oversættelse af den store Elizabethaners skuespil og sikkert med særlig glæde de historiske tragedier eller »krønikespillene« som blev oversat I 799-I8or. Det er Schlegels tyske Shakespeare som i de første årtier af forrige århundrede for alvor åbner den dannede læseverdens øjne for englænderens storhed, indtil den efterhånden afløses af den begavede skuespiller P. Th. Foersoms danske oversættelse (1807-16). Endnu Søren Kierkegaard henter sine mange Shakespearecitater fra Schlegel, den eneste han tilsyneladende har kendt trods alt en fattig erstatning for den originale dramatiker.

$\mathrm{Da}$ Grundtvig modtog opfordringen til at blive huslærer på Langeland, krævede han vished for, at han ikke skulle undervise $\mathrm{i} \gg$ levende sprog «. Først på Egeløkke er han begyndt at studere de tre moderne hovedsprog. »Jeg har fortsat tydsk og fransk læsning, og halvgennempløiet en engelsk Læsebog, Ting der fra Kundskabens Side aabne saare blide Udsigter i Fremtiden, naar min Aand kan nyde fransk Vittighed ved Siden af Sjækspirs Poesi og Lokes dybe Granskninger.« 
(20. nov. I 805). Måske sporer man den engelske begynderbog i den fonetiske stavning af digterens navn - som Grundtvig iøvrigt aldrig lærte at stave rigtigt.

I hvor stor udstrækning Grundtvig har læst Shakespeares skuespil før Englandsrejserne, er vanskeligt at afgøre. De dramatiske ungdomsværker »Optrin af Kæmpelivets Undergang i Norden,« I-II I 8og-I I, synes ikke at bære præg af megen førstehåndslæsning af Shakespeare. I udkastet »Om Poesi og Historie« ( I 8og), der helt er præget af tyske æstetiske teorier, hedder det: »Neppe findes der i nyere Tid en Digter, der er Hedning nok til at fremstille en Tragedie, uagtet Skakespear er ei langt derfra - «, men nogen påvisning findes ikke. Det er uden tvivl rigtigt, når Flemming Lundgreen-Nielsen i sin afhandling »Grundtvig, Skæbne og Forsyn« (1965) fremhæver, at »Literaturforskningen kan pege på enkelte lån og ligheder og vedføje dem som fodnoter. Selve ånden i »Optrin« er Grundtvigs egen, hverken Shakespeares, Schillers, Oehlenschlægers eller det hedenske Nordens«.

Måske alligevel nogle glimt af Schillers ånd. Grundtvig satte i sine unge år Schillers skuespil meget højt. Hyppigt citerer han »Die Braut von Messina (1803), Schillers mest antikiserende drama, hvor han efter eget udsagn ville forsøge sig som »Zeitgenosse des Sophokles, « mens det ægte folkelige skuespil »Wilhelm Tell« ( I804), der er mere i slægt med Shakespeares historiske skuespil, tilsyneladende ikke interesserer ham. 》Schiller gør han meget af, især hans »Braut von Messina $\ll$, hvori Treschow stemmede sammen med ham, men jeg ikke«. (Fr. Schmidt i »Erindringer om Grundtvig«, I948). Grundtvigs »Optrin« med deres kraftfulde retoriske repliker om hedenskab og kristendom er jo, som Oehlenschlæger ikke med urette skrev i et brev fra sin store udenlandsrejse $\gg$ Samtaler ... uden dramatisk Handling og Kunst. Han har i en vis Retning sejlet Historien paa det poetiske Kompas nærmere end jeg; men alle hans Helte bleve dog kun lyrisk-begejstrede Talsmænd for den raa Kraft.«»Optrin« er iøvrigt forsynet med et motto fra »Bruden fra Messina«, som dog blev strøget $\mathrm{i}$ anden udgave $\mathrm{r} 86 \mathrm{I}$. De ejer noget af det schillerske sproglige kongeskrud om historiske handlinger, men dramatisk spænding, lidenskab og humor - Shakespeares fornemste egenskaber - viger næsten overalt for religiøse og filosofiske betragtninger.

Først i England har Grundtvig selv opdaget den engelske digter William Shakespeare. 
2.

Naturligvis kendte Grundtvig digteren fra Englands historie, og i Verdens Krønike I8I 2 giver han ham den smukkeste omtale, ikke mindst $\mathrm{i}$ betragtning af de hårde domme, der her fældes til højre og venstre.

»I det I6tende Århundrede ... opstode to Skjalde, af hvilke den Ene, Spenser, ikke har mange Ligemænd og den Anden, Shakspear, ingen Overmand. Begge reiste de sig, ligesom den gamle Angelsaxer Cædmon, mellem Almuen og hørte til det forgangne Tidsrum, hvis Bautasten de reiste. Hvad der enkelt havde været omspredt hos Fortidens Balladesangere (Minstrels) som netop forstummede i Elisabeths Dage, var hos dem, især hos den Sidste, samlet tilstæde ... Shakspear ... bar den forsvundne Tids Billed i sig. Da han var opvoxet uden al lærd Dannelse, forkonstlede han ikke sin Natur og blev en sanddru Tolk af hvad der rørte sig i ham. Hans Hamlet, Macbeth, Kong Lear, Romeo og Julie, ere store Ballader, og hans historiske Samtaler ere Englands egenlige Heltedigt. Med Ret kalder Man alle disse Digte dramatiske, thi de opmane det Hensovede og stille os det livligt for Øie, men de undervise og om Forskellen mellem kristelige og hedenske Dramer. Før Kristus saa Digteren og Historieskriveren enhver Begivenhed som en sluttet Kreds; efter Kristus maa de se den som et Led i en fremløbende Kæde, og, uden at det dog fuldelig lykkes, maa de for at udrive den af sin Sammenhæng, gøre Vold paa deres indvortes Følelse«.

Opfattelsen af Shakespeare som digteren, der »rejste sig af Almuen og opvoksede uden al lærd Dannelse« skulle i høj grad blive levende under Englandsrejserne.

I det saftige og festlige »Rim-Brev til Nordiske Paarørende«, der indleder Nordens Mythologi ( $183^{2}$ ) klager digteren i andet afsnit over, at han ikke kan råbe englænderne op: »Men hvad der slumrer i Alfreds Grav/ Hører ei Røsten, mig Dana gav/, Alve-Dronningen, daanet der/, Ikke mit Kvad om Herre-Færd«. Der hentydedes naturligvis til Edmund Spensers allegoriske epos fra den Elizabethanske storhedstid »The Fairie Queene«, og denne »Ælve- eller Alfedronning « dukker jævnligt op i bogen som et symbol på det historiske England. Klagen over ikke at blive forstået af englænderne eller få lært deres vanskelige sprog fortsættes med en fri oversættelse af Norfolks replik i I. akt af King Richard the Second: »I am too old to 
fawn upon a nurse / Too far in years to be a pupil now/«»Og til at lalle paa Amme-Skiød/Er ikke længer min Tunge blød. / Men til som Pogen at nemme godt, / Dertil er nu mit Haar for graat/《

Men selv om Grundtvigs venner i Cambridge har beklaget sig over hans ru og håndfaste behandling af deres sprog: »He speaks English thro' a stone-wall! « har han i hvert fald nu lært sig at læse sproget, også hvor det udfoldes i overvældende fylde som hos Shakespeare (et sted oversat som »Spyd-Ryster!«).

Af bogen selv fremgår det helt klart, at fortroligheden med engelsk digtning, men i første række med de shakespeareske skuespil, i høj grad har været med til at hærde Grundtvigs uvilje mod den akademiske humanismes afhængighed af klassiske forbilleder og samtidig mægtigt har styrket hans tillid til den hjemmegroede, nordiske dannelses livskraft.

»At de Romaniserede Folk, eller Roman-Heltinderne, de berømte Græde-Kvinder over Roms Adonis, ei bragde det videre end til at balsamere hans Levninger (Quæ supersunt) på Spansk-Ægyptisk, opsminke Mumien på Fransk-Arabisk, og skrinlægge den i en Kiste af Italiensk, eller, om Man vil, Parisk-Cararisk Marmor; det ligner dem i det allermindste; men at selv Asa-Thor paa Øen har sat sin Ære $\mathrm{i}$ at slibe et mageløst Glas-Laag til Skiftingens Lig-Kiste, og spildt uhyre Kræfter paa at halvbygge et underjordisk Herkulaneum til Jetten Hrungners Grav-Capel, det er Klak for Skrift i LiterærHistorien, hvorom man maa bruge Shakespeares Ord, at Oceanet ei forslaar til at aftvætte den.«I noten hertil citeres Much ado about nothing (act. IV, sc. I):

- Oh! she is fallen / Into a pit of ink that the wide sea /

Has drops too few to wash her clean again!

Dette fornøjelige, men unægtelig noget besværlige billedsprog betyder jo blot, at selv om de romanske folk, Italien, Spanien og Frankrig har fordærvet deres eget væsen ved slavisk at efterligne klassisk kultur, så burde England på grund af sit nordiske slægtskab have holdt sin sti ren for denne fordærvelige indflydelse.

Det har Shakespeare, efter Grundtvigs overbevisning, formået. Og som en slående illustration til sin store kulturpolitiske tanke, som jo netop kommer til udtryk, eller snarere, udvikles af mange svøb, i denne bog, sætter han Shakespeare op mod den samtidige dramatiker Ben Jonson som den ulærde folkets søn over for den klassisk dannede 
humanist. Grundtvig må have moret sig hjerteligt, da han stødte på Ben Jonsons mindedigt over sin rival Shakespeare. Den afdøde hæves til skyerne, Jonson stemmer tonen højt, »he was not of an age but for all time«; han kalder Shakespeare »the star of poets, the sweet swan of Avon«. Men den akademiske humanist, hvis skuespil var efter Aristoteles regler og af Senecas og de gamle skribenters skole, føjer til, at Svanen fra Avon desværre manglede klassisk erudition, han besad kun »small Latin and less Greek!« Det smukke mindedigt er, som en af de nyeste forskere John Dover Wilson bemærker, præget af uvilje mod at anerkende, at Shakespeare virkelig skulle være en mere inspireret dramatiker end han selv. (The Essential Shakespeare, 1960). Hvorfor Ben Jonson da også formaner de yngre poeter til ikke, som Shakespeare, at forsømme klassisk lærdom. »Who casts a living line must sweat (such as thine are)/ and strike the second beat upon the Muses' anvil«. Grundtvig citerer flere af disse linier og føjer spottende til, at de vel skal betyde, at »hver Gang en lille Athene kom hoppende ud af hans (Shakespeares) hjerne, maatte hun paa Ambolten, for at faae sin rette Skabning, og blive ordentlig koldbrystet, kan jeg tænke«.

Her indskyder Grundtvig et lille hjertesuk over, at Shakespeare »aldrig selv kom til nogen Universal-Historisk Anskuelse« - [han kendte jo ikke Grundtvig]. Men det »kom sikkert af, at han fattedes Nordens Myther, som kun spøgede for ham, lig Hamlets Aand... men selv om han havde haft både Mytherne og Anskuelsen, vilde han dog neppe avlet en tilsvarende Videnskabelighed, thi for at kunne det, maatte han virkelig vundet Ben fohnson, hvem han nu kun forbausede, og blev vist ikke dyrebar, før han var død, og kunde ei meer lade Falstaff lee sin Mave itu ved Amboltens Lov-Tale over Forhammeren. Aanden spilder aldrig sine Kræfter, om det end synes saa, og Shakspear havde derfor kun, hvad der var brugeligt til at vække den endnu ikke ganske uddøde Kamp på Øen, og til i sin Tid at opmuntre Frænderne i Tydskland, og i Norden, hvor Mytherne var glemte, som Kæmperne fordum, til Rom havde anden Gang fyldt sine Synders Maal, og var moden til Undergang «.

Inspireret af Ben Jonsons ejendommelige, på en gang ærbødigtkærlige og kritisk-rivaliserende mindedigt over Shakespeare vil Grundtvig nu vise sine læsere, hvad pennen formår, når den ikke »pløier med Romernes Kalve« - altså efterligner den latinske stil. Det gør han besynderligt nok, ved at kalde Herkules op af graven og lade ham 
genopleve sin sidste store prøve, da han skulle hente helvedhunden Cerberus op af dødsriget. »De staae lyslevende ved Siden af hinanden som William Shakspeare og Ben Johnson og lære os paa Een Gang, baade hvad det er, den Romerske Aand har pint ihjel og hvad Nordens Aand formaar, naar den bryder de Romerske Lænker. $\mathrm{Ja}$, det er en universal-historisk Kendsgerning, at det Eneste i de sidste fem Aarhundreders Literatur, som fortjener at sammenlignes med Grækernes Mester-Værker, er Shakspears Værk som Skaber eller dog som Fader. Og hvordan blev han vel til den Shakspear, den ny Herakles, ikke Wielands (enten Shakespear eller Hercules) Mand af Middel-Størrelse, men den virkelige Helt af Gudernes Æt, der gik gennem Helvede ubrændt, og førde, til overflødigt Bevis, Cerberus med i sin Lænke«. Ja, det lykkedes netop, fordi han var inspireret af »Nordens KæmpeAand, af hvis Drift han løb tids nok ud af Skolen« og ikke lod sin ånd fordærve af latin og græsk!

»Ingenlunde, « fortsætter Grundtvig, »vil jeg hermed sige, at Shakespear staar ene i England, nei, Spenser og Baco [Francis Bacon] staae hos ham, og mellem AsaThor og Jetten Hrungner [altså Nordens And og Romeraanden, for at oversætte Grundtvig til Grundtvig!], som yder et anderledes stort og lærerigt Skue-Spil end den Tydske Hane-Fægtning. . .«

Så følger det afgørende sted, hvor »Shakspear « indsættes i sin hovedrolle som kronvidne for Grundtvigs klagemål mod latinen, som selve »Kraftbeviset« for hans kulturpolitiske drøm om at indvarsle en nordisk-angelsaxisk Renæssance eller Genfødelse. »Jeg peger her kun paa Shakespear, som Hoved-Manden, for at Læserne paa ham skal see, det er ligesaalidt den Classiske Dannelse, der har hævet den Engelske Literatur, som det er Syndfloden af Latinske Ord der pryder og forstærker det Engelske Sprog, men at det tvertimod er den ægte Nordiske Kraft, der, med meer og mindre Held, stræber at giennembryde den Romerske Mur«.

Dermed har den fra Romantiken overtagne beundring for »Universal-Geniet« nået sit højdepunkt. Men rigtignok på et helt nyt grundlag. Vi er langtfra Sturm- und Drang-poeternes æstetisk-filosofiske tilbedelse af Shakespeares teater som en art åbenbaring. Nu hedder det i Grundtvigs eget sprog om »Skjalden Shakspear«, at »der vil neppe være et Kapitel i den store Universal-Historie, vi forvente, hvortil ikke den mest passende Overskrift skulle findes i Shakspears Histori$e r$, som de saa træffende kaldes«. 
3 .

I 9. brev af Grundtvigs Breve til hans Hustru under Englandsrejsen (1920) oplyser han under 22/6 1829: 》Jeg har faaet Fingre paa en storstilet Shakspear, som jeg læser daglig i ... Ved et Lykketræf traf jeg den paa Holborn hos en Boghøkerske og fik den godt indbundet i 6 Bind stor Octav for et Pund «. Det er antagelig »Works of W. Shakespeare, carefully revised and corrected «, I-VI, I 745, som er opført i fortegnelsen over Grundtvigs bogsamling.

Det er fornøjeligt at se Shakespeare dukke op gang på gang, snart i teksten, snart $\mathbf{i}$ fodnoter, altid på engelsk, som en bjergbæk i en broget snart solbelyst, snart dunkel og tåget skov. Muntert kritiske bemærkninger om tyske videnskabsmænds fantasiløse betragtninger over mytologi og religion kommenteres med repliker fra »As you Like it«, III akt, hvor Touchstone udspørger hyrden Corin om hans »philosophy« og får til svar en henrivende strøm af komiske banaliteter. Grundtvig har kunnet more sig med den lystige Shakespeare!

Væsentligere er naturligvis den enestående betydning Grundtvig tillægger Shakespeare som det klareste udtryk for angelsaxisk og dermed nordisk ånd. Ligesom hans begrundelse oplyser, hvorledes han nu bestandig får sine egne forventninger til en hjemmegroet folkelig dannelse og en dertil svarende anti-latinsk kulturpolitik styrket. »I England havde man ingen Luther, og trængde dog til Een, derfor blev Kirke-Ordet aldrig levende hos dem, men desmere forbausende er den Literatur de fik paa Modersmaalet; thi at den Engelske Bibel ikke, som vores, er en Oversættelse af Luthers, men staar som Bog høit over hans (Grundtvig tænker her på King James Version, I6 I I), og at det ene var den Engelske Literatur, der siden Reformationen skabde fra Aandens Side en Mod-Vægt til den Franske, det veed Man, eller det skal Man lære, hvor Man vil blive klog ei blot paa Død og Bogstav-Skrift, men paa Liv og Aand!« Tanken føres videre $\mathrm{i}$ en fodnote til denne håndfaste erklæring: »Spørger Man, hvor Engelland fik en saadan Literatur fra, naar det levende Ord er Skriftens Moder, og Kirke-Ordet ikke levede, da huske Man, at der var Minstreller [et andet sted kaldes de »Harpere «] til der blev Shakespearske Skuespillere, og Parlaments-Talere til den Dag i Dag, altsaa Leilighed nok for Folke-Aanden til, saalænge der var Kraft, at holde det tilsvarende Ord ilive«.

Det er således ikke blot de gamle manuskripter i British Museum, 
Exeter og Cambridge som har åbnet forskerens øjne for slægtskabet mellem engelsk og nordisk ånd. I lige så høj grad er det den voksende fortrolighed på engelsk med Shakespeares »Universal-historiske Skuespil«, der for Grundtvig afslører den dybe sammenhæng mellem nordboer og angelsaxer. Om de nordiske myter og sagn hedder det $\mathrm{nu}$, at deres indre sammenhæng først herovre blev digteren klar. »Hvor de Nordiske Old-Sagn, jeg kalder saa, med Nornekvadet (d. v. s. Vøluspá) i Spidsen, nærmest har hjemme, det kan jeg see, thi det er aabenbar hos Bjovulfs-Drapens, Kædmons, og Shakspears Fædre, som Nordens mest poetiske eller prophetiske Stamme, og først da jeg kom efter det, begyndte jeg at hitte Rede i vore Old-Sagn.«

For også på dette område kan Shakespeare udnyttes. Grundtvig har grublet over de tre berømte hexe, »the weird sisters« i Macbeth ( I. akt, 3. scene). Man husker, at de uhyggelige gamle kvinder danser i ring om Macbeth og hans ledsager Banquo og i dunkle ord spår begge mænds vidt forskellige skæbne. Er de mon ikke en folkelig grov udgave af skæbnegudinderne, af selve Nornerne? »Da vi ingen Angel-Sachsiske Kvad har tilbage i deres Hedenske Dragt, finder vi naturligvis ikke Nornerne egenlig omtalte, men des mærkeligere er det, at vi finde »Wyrd« (Urd), som det slaaende Udtryk for Skæbnen, thi ogsaa i de Hedenske Kvad var det kun Urd som blev nævnt. Vi finde imidlertid ogsaa Navnet i Pluralis (wyrdas) og kan see, det har betegnet Nornerne, og selv Tretallet spore vi i Sagnet om de tre Urde-Søstre (weird Sisters), som spaaede Macbeth hans Skæbne.« Denne etymologi søger Grundtvig at underbygge med sine fund af glosen »wyrdas« både hos den gamle Chaucer - hvor betegnelsen vitterligt brnges til oversættelse af det latinske »Parcæ« - , hos den skotske digter Gawin Douglas (d. I522) og i Andrew Wyntouns Skotske Rimkrønike (ca. I 400) hvorfra Shakespeare har hentet sine tre hexe. Den sidste var først ret nylig blevet fremdraget, da Grundtvig var i England, og det vidner om hans flittige læsning derovre, at han også har fundet denne gamle »Orygynale Cronikyl«, som naturligvis har moret Rimkrønikens elsker, da den også begynder med verdens skabelse. Til gengæld drister den danske filolog Grundtvig sig til at påstå, at hans egen samtidige Walter Scott (her altid kaldet Sir Walther og stavet på tysk) i »Tales of a Grand-Father« ikke har kunnet finde ud af, hvem »disse Damer« i grunden er!

»The Tragedy of Hamlet, Prince of Denmark « ( 1603 ) har naturligvis beredt Grundtvig en særlig glæde. Han har læst den allerede i 
sin ungdom, i Schlegels tyske oversættelse - og han har dengang dannet sin mening om den efter den tyske forfatter Jean Paul Richters æstetiske teorier i »Vorschule der Aesthetik« ( I 804), som han har læst umiddelbart efter dens udgivelse. På dette grundlag var Hamlet blevet hårdt bedømt. Tragedien var både uhistorisk og unordisk ( $\mathrm{Ny}$ Minerva, 1807). Det er en fejl, at dette drama udspilles på en »Jordplet, i hvilken ganske andre Erindringer ere rodfæstede«. Digteren kender ikke det gamle Norden grundigt, han har udrevet »et Led af den Kiæde, han enten burde givet heel, eller ladet være ganske urørt.«

I »Nordens Mythologi« er vi lykkeligvis kommet langt bort fra disse tyske abstrakte teorier om hvad en tragedie må have lov at være. Det er også for Grundtvig ganske ligegyldigt, at Shakespeare fandt emnet, ikke hos Saxo, som han ikke kendte, men i Belleforest's »Histoires Tragiques« ( $158 \mathrm{I}$ ), en fransk samling dystre noveller fra mange lande, at emnet er forskudt både i tid og rum, og at hele den berømte tragedie er langt stærkere præget af Montaignes radikale skepsis end af det gamle djærve eventyr hos Saxo - som Axel Olrik jo endda ville tillægge orientalsk oprindelse. Nej, denne historie er skænket den engelske dramatiker af langt højere magter!

»Vil Man see, hvad blot en lille Stump af en Bog som Saxos kan giøre, naar den falder i gode Hænder, da læse Man Shakespeares Hamlet, skiøndt den vistnok ikke er udsprunget af nogen Bog, men af Nordens Aand, som i Engelland stedse har bevaret en Forkiærlighed for Danmark, der ordenlig er folke-psychologisk og universal-historisk mærkværdig! «

Langt senere i den tykke bog optager han tanken påny. 》Saaledes er det i sin Orden, at Shakspear fandt sig bevæget til at dele sit udødelige Navn med Amlet (Hamlet), skiøndt det er løierligt nok, at han ikke vil have ham til Engelland; men jeg kan dog ikke slippe denne Materie, før jeg har peget paa Amleds mythiske Halv-Broder eller Genfærd, Danskeren Havelok, om hvem Engelske Krøniker sige, at Svenn Tveskiæg og Knud den Store kaldte ham deres Frænde, som de kom til Engelland for at arve«.

Grundtvig tænker her på »The Lay of Havelock the Dane«, et stort episk digt på ca. 3000 vers fra $\mathrm{I} 200$-tallet, hvis brogede beretninger antagelig har forbindelse med danske eller norske vikinger og deres bedrifter. Havelock menes at være en walisisk form for Olav eller Anulf, men digtet har næppe nogen forbindelse med Hamlet. I 
denne sammensætning bliver det imidlertid for Grundtvig et nyt, veltalende vidnesbyrd om det nære slægtskab mellem nordisk og angelsaxisk ånd, et hovedtema i hele den store bog om »Nordens Mythologi eller Sindbilled-Sprog $«$.

Hvor rammende er det da ikke, at Grundtvig, da det gjaldt om at tirre englænderne til selv at gøre noget ved deres egen gamle angelsaxiske digtning og omsider få den udgivet, citerer Shakespeare for sine videnskabelige kolleger: »Langtfra derfor i Udsigten [hans egen Bibliotheca Anglo-Saxonia Prospectus, London MDCCCXXXI] at skaane den Engelske Ømfindtlighed, stræbde jeg netop med Flid at saare den saa dybt som mueligt, og sagde, blandt Andet, reent ud: Dersom jeg var en Engelsk istedenfor en Dansk, Digter og Historiker, da ville jeg tiltale Fædrenelandet med den »udødelige Sangers« Ord:

Dorskere er du end Urten, som raadner

Paa Fedme-Jords-Bredden af Lethe i Mag,

Vil du dig ei røre endnu; -

(Phenix-Fuglen, 1840).

(Citatet er Genfærdets råb til sønnen i »Hamlet«, I. akt, 5. scene: »And duller shouldst Thou be than the fat weed / That rots itself in ease in Lethe's wharf, / Wouldst Thou not stir.«).

4 .

Grundtvigs forhold til den store Elizabethanske dramatiker er da rent literært og historisk, som man ser. Han har næppe ulejliget sig med at overvære et Shakespearesk stykke på teatret, Grundtvig nærede som bekendt ringe interesse for skuespilkunst. Til gengæld har han læst ham »med hjertekulen«, oplevet historiens ånd gennem de »universalhistoriske samtaler « i de store tragedier, glædet sig over sprogets fylde og rigdom, og nu er det den engelske Shakespeare, ikke en fortyndet og »forædlet « tysk Shakespeareudgave. Væsentligt er det, at han ikke nøjes med at videreføre den i almindelige vendinger udtrykte grænseløse beundring for det store britiske geni, sådan som Henrik Steffens og tyske romantikere havde indprentet ham det $\mathrm{i}$ århundredets første år. I England har Grundtvig virkelig sat sig til at læse Shakespeare på hans eget sprog. De store tragediers vældige pust af Englands blodige middelalderhistorie har grebet ham. Disse tragedier med emner fra Holinsheds krønike og Rosekrigenes tid, King John, King Richard II, Henry IV, Henry V og ned til Henry VIII er jo virkelig en slags »Optrin af Kæmpelivets Undergang«i England, 
sådan som Grundtvig - med ringe held - havde forsøgt det et kvart århundrede tidligere. Sikkert har han kunnet fornøje sig over den strålende lyriske festivitas i »As you like it«, som han flere gange citerer, og »A Midsummer Night's Dream《; og den beske livsvisdom i Macbeth, King Lear og Hamlet har ramt beslægtede strenge $i$ hans eget digterhjerte. Men det er dog frem for alt den formentlig ulærde, hjemmedannede »almuesøn« og digters storhed, der mægtigt har styrket Grundtvigs kulturpolitiske filosofi, som den kommer til orde i dette værk. Og her bruger han William Shakespeare helt efter sit eget hoved, uden at kaste blot et sideblik til mulige biografiske oplysninger - de er jo også sparsomme - til teaterhistorien, eller de literære traditioner og påvirkninger. Shakespeare er et guddommeligt geni, det vidste alle tyskdannede romantikere. Men for Grundtvig er han også, efter at han i England og på hans eget sprog har lært ham at kende, en nordisk ånd, en fostbroder i kampen mod den latinske dannelse, der siden I300-tallet havde svinebundet Nordeuropa, og især de nordiske lande omkring Vesterhavet. Grundtvig kan uden vanskelighed for sig selv begrunde denne opfattelse af Shakespeare, og forstår med frodigt lune og på helt selvstændig vis at bruge den bogen igennem.

Kærligheden til Shakespeare bevarede Grundtvig. Endnu i Mands Minde citerer han den engelske digter, (XLVII, I6. november) og beundringen for engelsk digtning glemte han aldrig. Frederik Hammerich fortæller, at han få dage før Grundtvigs død læste et gammelt angelsaxisk digt for ham. Grundtvig kendte det godt fra en antologi, han selv i sin tid havde benyttet, »Hickes' Thesaurus«. »Jeg læste bl. a. begyndelsen for ham, hvor det hedder saaledes. . .

\author{
Du vældige Stenvold, \\ Styrtet af Skjæbnen! \\ Rokket og rævnet \\ Er Ringmurens Kjæmpeværk, \\ Tagene borte, \\ Taarnene rave, \\ De mægtige Porttaarne; \\ Murværket rimslaget, \\ Brustne Skandserne; \\ Brudt ned, styrtet ned, \\ Undergravet, \\ Af Ildens Magt! (The Ruin).
}


»Ja, sagde Grundtvig, her er noget af det storslaaede, som Engelskmænd altid har haft sin Styrke i. Man kommer uvilkaarlig ved at høre det, til at tænke paa hele den angelsaksiske Literatur; for den er selv en rigtig stolt Ruin og kan derfor godt lignes med den Stad i Ruiner, hvorom den gamle Skjald har sunget.«

Vi talte endnu noget om Angelsakserne, og han gav mig Digtet hjem med; saa forlod jeg ham og anede mindst, det var sidste Gang, jeg skulde se ham i dette Liv.« 